\title{
Bir Armenturerwnaltunt.
}

Eine Bufaummenftellutitg

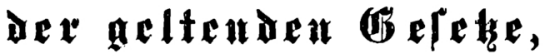

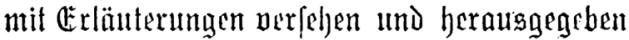
pon

\$3. Gteffertịagen, Beigeoroneter.

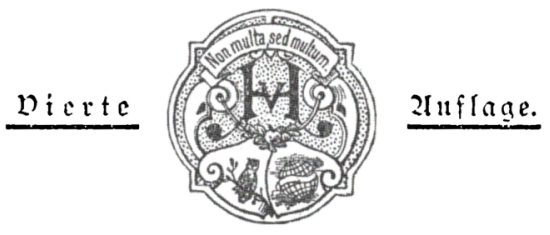

Z3erlint.

I. I. Geines berlag.

1887. 
